\title{
The Paleozoic and Mesozoic vertebrate record of Venezuela: An overview, summary of previous discoveries and report of a mosasaur from the La Luna Formation (Cretaceous)
}

\author{
MARCELo R. SÁnCHEZ-VILLAGRA, Zürich; WinAND BRINKMANN, Zürich \& RobERTo Lozsán, \\ Barquisimeto
}

with 4 figures

\begin{abstract}
SÁnChez-Villagra, M.R.; BRINkMANN, W. \& LozSÁn, R. 2008. The Paleozoic and Mesozoic vertebrate record of Venezuela: An overview, summary of previous discoveries and report of a mosasaur from the La Luna Formation (Cretaceous). - Paläontologische Zeitschrift 82 (2): 113-124, 4 figs., Stuttgart, 30. 6. 2008.
\end{abstract}

\begin{abstract}
Most reports of Paleozoic and Mesozoic vertebrates from Venezuela are anecdotical, with few detailed descriptions of mostly 'fish' groups. Synapsids (e.g., mammals) are totally unknown, and dinosaurs are only reported from the La Quinta Formation. At least 14 formally recognized geological formations contain fossil vertebrates, most from the Central and Western parts of the country. In the Devonian there is a significant contrast between the vertebrates of Venezuela and Colombia and those of more southern parts of South America. Marine reptiles are present in a few localities in western Venezuela, and are very fragmentary, with one exception. A mosasaur from the Cretaceous La Luna Formation, reported here for the first time, is the most complete vertebrate (tetrapod) from the Cretaceous of Venezuela, and includes a partial skull and a few postcranial remains.
\end{abstract}

Keywords: fish • reptile $\bullet$ La Luna $•$ South America • biogeography

Kurzfassung: Berichte über paläozoische und mesozoische Wirbeltiere von Venezuela sind weitgehend anekdotisch, mit der Ausnahme von wenigen ausführlichen Beschreibungen, die meistens 'Fischgruppen' betreffen. Synapsiden (z.B. Mammalier) sind völlig unbekannt und Dinosaurier sind nur aus der La Quinta Formation nachgewiesen. Mindestens 14 formell anerkannte geologische Formationen haben fossile Wirbeltiere geliefert, meistens aus den zentralen und westlichen Landesteilen. Im Devonium fällt zwischen den Wirbeltieren aus Venezuela und Kolumbien sowie jenen aus südlicheren Regionen Südamerikas ein wesentlicher Gegensatz auf. Marine Reptilien sind aus wenigen Lokalitäten von Westvenezuela nachgewiesen. Diese Funde sind mit einer Ausnahme sehr fragmentarisch. Über einen Mosasaurier aus der kretazischen La Luna Formation wird hier erstmals berichtet. Dabei handelt es sich um das vollständigste Wirbeltier (Tetrapode) aus der Kreide von Venezuela. Das Material umfasst einen unvollständigen Schädel und wenige postcraniale Reste.

Schlüsselwörter: Fische • Reptilia • La Luna • Südamerika • Biogeographie

\section{Introduction}

Information on pre-Cenozoic fossil vertebrates from Venezuela is dispersed in the literature, and much of it is published in local papers. Many of the reports are simple communications in the notes presented by ODREMAN RIVAS \& MEDINA (1984, see also ODREMAN RIVAS 1997), and in the Léxico Estratigráfico de Venezuela (Ministerio de ENERGía Y MinAs 1997). There are also several notable publications nowhere summarized. In addition, we have information based on discussions with local geologists and on our own old and new localities. We summarize here these reports and provide contextual information that is relevant to understand the significance of the fossils. Although some of the information presented here is anecdotical, we think that it gives clues for future exploration and research, as Venezuela remains a potentially rich source of vertebrate fossils for the Paleozoic and Mesozoic.

Addresses of the authors: Marcelo R. Sánchez-Villagra and Winand Brinkmann, Paläontologisches Institut und Museum, Universität Zürich, Karl Schmid-Strasse 4, CH-8006 Zürich, Switzerland; e-mail <m.sanchez@pim.uzh.ch>. - Roberto Lozsán, Barquisimeto, Venezuela. 
The pre-Cenozoic vertebrate record of Venezuela consists of mostly isolated occurrences, for the most part the result of occasional findings of local geologists who have stumbled upon fossils. There is not a single site from which a truly diverse vertebrate fauna has been described, although some fish assemblages from the Sierra de Perija may provide this as soon as they become well-researched (YOUNG \& MOODY 2002). Ample exposure of Paleozoic rocks are known from the Sierra de Perijá, a northward extension of the Andes along the Colombian-Venezuelan border, reaching $3688 \mathrm{~m}$ at Monte Plano (GonZalez DE JuANA et al. 1980).

In most cases of reports resulting from oil exploration or occasional work of geologists, the original samples are lost. Most of these specimens were part of temporary collections of private companies, which no longer exist or ended up in private hands or got lost. More recent work by JOHN M. MOODY (b. 1952) and collaborators has resulted in a modest but pioneering collection at the Museo de Biología de la Universidad del Zulia (MBLUZ), in Maracaibo.

We will use a chronological presentation of geological formations with vertebrate fossils. The names of the formations follow the most recent Léxico Estratigráfico de Venezuela (MinisTerio de ENERGía Y MiNAS 1997). Much information until the time of the publication is found in the second edition of the classic work of LIDDLE (1946), but approximately $40 \%$ of the formation names used by LIDDLE (1946) are no longer in use. The MINISTERIO DE ENERGÍA Y MINAS (1997) has lists of synonymies for each valid formation. The validity of several formations has been and continues to be a matter of controversy among stratigraphers in Venezuela the discrepancies reflect different philosophies on what a formation is, besides nomenclatural issues, which in many cases have also played a role. Geologists with a European background have tended to see formations as chronostratigraphic units, whereas those with an American background see them as lithostratigraphic units.

In this paper we make reference to the main political divisions of Venezuela. Administratively, Venezuela is divided into 23 estados (states) and the federal district of Caracas. The islands of Margarita, Coche and Cubagua collectively form the state Nueva Esparta, 72 remaining islands are federal dependencies. The states are further divided into municipios.

Abbreviations: AMNH, American Museum of Natural History, New York and NHM, Natural History Museum, London (formerly BMNH, British Museum Natural History).

\section{Chronological overview of the Paleozoic and Mesozoic vertebrate record of Venezuela}

\section{Caño Grande Formation, Lower - Middle Devonian}

BOWEN (1972: 740) mentioned the presence of teeth of indeterminate fish in the Caño Grande Formation (Río Cachirí Group), Perijá, Zulia State. This would be the oldest record of vertebrates from Venezuela. The age of the deposits is reported to be Lower and Middle Devonian, and the paleoenvironment is one of shallow waters, perhaps marine or brackish (MINISTERIO DE ENERGÍA Y MINAS 1997). ODREMAN RIVAS \& MEDINA (1984: 66) doubted the validity of this report, based on the (purportedly well supported) age of the deposits and the marine habitats represented in them. According to these authors, the groups of fishes with teeth at the time were all freshwater dwellers and not marine. This is incorrect, as there were marine 'fish' with teeth at the time (BENTON 2004). So little information is currently available on this vague report that its importance remains questionable.

\section{Campo Chico Formation, Middle - Late Devonian}

A diverse and new fish fauna of Gondwanan affinities was described by YOUNG \& MOODY (2002) from the two localities and several horizons belonging to the Campo Chico Formation in the Sierra de Perijá, Zulia State. About 400 specimens are listed from the collections of the Museo de Biología de la Universidad del Zulia, with additional copies or some parts deposited at the Museum für Naturkunde in Berlin.

This assemblage is dominated by placoderm remains, in contrast to the also Devonian assemblages from Brazil and Bolivia containing chondrichthyans and acanthodians. It contains the first Devonian record from South America of three major clades: dipnoans and antiarch and phyllolepid placoderms, otherwise widely distributed in most other continents.

The fauna includes what was described by YouNG \& MOODY (2002) as a new genus and species, Venezuelepis mingui, and the new species Bothriolepis perija, both antiarch placoderms. These two forms were compared by these authors with species from Antarctica. The fauna contains fragmentary remains of a phyllolepid placoderm that is similar to Austrophyllolepis from southeastern Australia. There are also spines belonging to the acanthodian Machaeracanthus and to the chondrichthyan clade Antarctilamnidae.

There were two collecting areas, about $70 \mathrm{~km}$ west of Maracaibo, approximately $3 \mathrm{~km}$ apart from each other and an estimated $200 \mathrm{~m}$ of separation in the stratigraphic section. The sites are located in the Caño Colorado region, between the Palmar and Socuy Rivers. 
YouNG et al. (2000) hypothesized that this Venezuelan fish fauna was located in the northern Gondwanan margin and is indicative of a non-marine dispersal between Gondwana and Euroamerica in the Late Devonian. In view of the distribution of several invertebrate groups, these authors suggested close connections with what is now Eastern North America during the EarlyMiddle Devonian.

YOUNG (2005) reported on phyllolepid placoderms from central Australia as old as those from Venezuela reported by YOUNG \& MOODY (2002). YouNG (2005) discussed the temporal and spatial distribution of these placoderms in the Late Devonian, emphasizing the significant geographic expansion on distribution that the Venezuelan record represents (in northwestern Gondwana, otherwise with no remains of this group) (cf. YOUNG 2005: fig. 5).

There is a discussion in the literature on tectonics about the possibility that western Venezuela may not be part of the northwestern margin of Venezuela but instead be allochthonous (e.g., FORERO 1990; MOJICA \& Villaroel 1990; AVÉ LALLEMANT \& SISSON 2005). YOUNG \& MOODY (2002: 166) suggested that their interpretation of the biogeographic affinities of this fish assemblage speaks against such a hypothesis (see also MOODY 1990, 2005).

\section{Río Palmar Formation, Lower Pennsylvanian}

ODREMAN RIVAS \& MEDINA (1984: 66) reported teeth and fragments of fin rays, perhaps Actinopterygii, from around the Río Cachirí (Caño del Noreste), Perijá, Zulia State.

\section{Palmarito Formation, Carboniferous - Lower Permian}

PIERCE et al. (1961: 349) reported the presence of indeterminate fish from the area around La Grita, Táchira State. According to these authors, a series of organisms such as ostracods and foraminifera indicate a middle Pennsylvanian to early Permian age for the fossil-bearing strata, as reported also in MINISTERIO DE ENERGíA Y MiNAS (1997).

\section{Undeterminate Late Paleozoic Formation}

SÁNCHEZ \& BENEDETTO (1979) named a new genus and species, Archaeopycnodon riveroi, from fragmentary dental remains and referred it to the Pycnodontiformes. The authors did not report a formation name for the rocks containing the fossil, but provided a stratigraphic column expanding from the middle Pennsylvanian up to the Lower Permian, with the fossil coming from the upper part of the section. The locality is between the cities of Carora and Trujillo in Western Venezuela, some 16 $\mathrm{km}$ north-west of Carache.
SÁNCHEZ \& BENEDETTO (1979) explained that this may represent an extension in the temporal distribution of Pycnodontiformes, previously starting in the early Triassic. This occurrence is doubtful, because the oldest known fossil record of a genuine pycnodont is Late Triassic in age (P. Forey, pers. comm., October 2006), and this dentition could belong to a convergent durophagous fish. In view of this, further investigation of the site for more remains and for precise aging of the rocks would be relevant. If Archaeopycnodon riveroi is indeed a pycnodontiform and the age of the site is indeed pre-Triassic, this occurrence should be significant in understanding the evolutionary tree of basal actinopterygians (ARRATIA 2004; HuRLEY et al. 2006).

\section{Tinacoa Formation, Lower - Middle Jurassic}

The sedimentary outcrops in the Río Mocoita belonging to the Tinacoa Formation contain fish referred to Lepidotes (BOWEN 1972: 754). In the palaeontologic collections of the NHM (formerly BMNH) there is uncatalogued material labelled as Lepidotes from Venezuela, with the name BOWEN as collector. The material belongs indeed to Lepidotes-like fish and consists of two aggregations of some 30-70 scales respectively and other smaller isolated pieces of sediment with a few scales. ODREMAN RIVAS \& BENEDETTO (1977) reported more Lepidotes remains from this formation, from both the Macoita River and from the mouth of the Caño Caliche into the Río Palmar, in Central Perijá. OdREMAN RIVAs \& MEdina (1984: 68) stated that the discovery of plant remains of the genera Ptilophyllum and Otozamites in the latter of these two localities suggest a Jurassic age for this unit and not early Permian, as it had been reported in the past. These two plant genera are indeed of Mesozoic age (P. KENRICK, pers. comm., October 2006).

\section{Macoita Formation, Middle - Upper Jurasssic}

BOWEN (1972) mentioned the presence of fossil plant remains and fish scales, some $200 \mathrm{~m}$ upstream from Boca Surucunaca, Zulia State. As summarized in MINISTERIO DE ENERGÍA Y MINAS (1997), the most recent studies suggest a Jurassic age for this Formation. BENEDETTO \& ODREMAN RIVAS (1977) suggested that the Macoita Formation probably correlates with the middle portion of the La Quinta Formation.

\section{La Quinta Formation, Jurassic}

This formation is of special significance, as from it the first Venezuelan dinosaur has been reported. There are extensive exposures of the La Quinta Formation across the Venezuelan Andes. The formation at its type locality was reviewed by SCHUBERT (1986).

KUNDIG (1938) reported fish remains from the La Quinta Formation, which were assigned by A. SMITH- 
WOODWARD to Lepidotes. This material is deposited in the Department of Palaeontology of the NHM.

RUSSELL et al. (1992) referred a few cranial remains and teeth to the ornithischian cf. Lesothosaurus sp. (as did SÁNCHEZ-VILLAGRA \& ClARK 1994). BARRETT et al. (2008) questioned this assignation, given the lack of diagnostic features in the samples and the problematic issue that only a unique combination of character states diagnoses Lesothosaurus from other ornitischians (BUTLER 2005). According to BARRETT et al. (2008) the material described by RUSSELL et al. (1992) exhibits a number of ornithischian symplesiomorphies. BARRETT et al. described additional disarticulated and associated elements that suggest that at least two distinct taxa are present in their studied sample, including a non-cerapodan basal ornithischian and an indeterminate basal saurischian, with other dinosaur taxa perhaps represented in the sample as well.

MOODY (1997) described five isolated theropod teeth from the same quarry in which the material studied by RUSSELL et al. (1992) was found.

A postcranial bone of a large vertebrate was found in exposures around La Fundación, Táchira State (O. ODREMAN RIVAS, pers. comm. to MRS-V, 1992). Its identification has been problematic, ranging from a tarsal element to a vertebral fragment. This specimen was deposited in the collections of the Museum of Biology of the Universidad Simón Bolívar by MRS-V in 1992.

\section{Río Negro, lower Cretaceous, pre-Aptian}

Remains of teleost fishes, from the northern flank of the anticlinal of La Porra, near the small town of La Peña, Lara State, were reportedly collected by O. MACSOTAY and deposited at the Ministerio de Minas at the time (OdREMAN Rivas \& MEdina 1984). Macsotay (1980) suggested a Neocomian age for this formation.

\section{Apon Formation, Cretaceous, Aptian - Albian}

The Apon Formation, of Aptian - Albian age, is exposed in the Sierra de Perijá (Zulia) and in the Venezuelan Andes, including Táchira, Mérida, Trujillo, and Lara states (MINISTERIO DE ENERGÍA Y MINAS 1997).

MAISEY \& MOODY (2001) described a new species of the teleost Araripichthys from the Lower Cretaceous (Aptian) Machiques Member of the Apon Formation, Venezuela. Araripichthys axelrodi is the oldest and most basal member of the genus, the phylogenetic position of which is highly contested. Alternative hypotheses include placement as an advanced teleost (within acanthomorphs), or at a much more primitive level within teleosts (as an elopocephalan incertae sedis). MAISEY \& MOODY (2001) suggested that Araripichthys and the Ferrifronsidae share some features with higher teleosts (clupeocephalans, neoteleosts, acanthomorphs), but lack many other characters of those groups. Araripichyidae and Ferrifronsidae are regarded as basal clu- peocephalans close to Pachyrhizodontoidei by CAVIN (2001). MAISEY \& MOODY (2001) hypothesized that Araripichthys originated in the Pacific or western (Caribbean) Tethys and apparently dispersed eastward by the Albian.

MOODY \& MAISEY (1994) reported on a fish assemblage from the Apon Formation including ichthyodectids, pycnodontids, unidentified elopocephalans, and the aspidorhynchid Vinctifer. An additional assemblage from the La Luna Formation reported by these authors is discussed below. MOODY \& MAISEY (1994) stated that "the occurrence of Vinctifer is of considerable biostratigraphic and biogeographical interest in view of previous claims about its temporal range and distribution. Vinctifer ranged throughout the Aptian and Albian, especially in Brazil, where its occurrence may be of ecological significance in marking a transition from enclosed basinal environments to more open marine conditions".

MoODY \& MAISEY (1994: 1) also mentioned the presence of a large ichthyosaurian vertebra from the Apon Formation.

\section{La Luna Formation, Cretaceous, Cenomanian - Campanian}

The La Luna Formation is of Cenomanian - Coniacian age, according to ODREMAN RIVAS \& MEDINA (1984), but MOODY \& MAISEY (1994) hypothesized a Cenomanian - Santonian age and the MINISTERIO DE ENERGÍA Y MiNAS (1997) a Cenomanian - Campanian age. The La Luna Formation, consisting of black shales, is the source of a great portion of the rich oil deposits in the Maracaibo Basin (MINISTERIO DE ENERGíA Y MINAS 1997). The La Luna Formation contains reportedly euxinic environments, with waters of contested depth. BOESI et al. (1988) suggested depths of around $100 \mathrm{~m}$ in the Turonian up to $800 \mathrm{~m}$ in the Campanian. The great extension of this major geological unit, ranging from the Sierra de Perijá to the Mérida Andes and to Colombia, via the Maracaibo Basin, makes it likely that different ages and environments are represented in its rocks (TRIBOVILLARD et al. 1991).

Sediments of this formation in the Carora area, Lara State, contain teleost fishes (A. USECHE pers. comm. to ODREMAN RIVAS \& MEDINA 1984: 69). From this same unit, but from the area of Chejendé, Trujillo State, the geologist I. FIERRO (in ODREMAN RIVAS \& MEDINA 1984) found indeterminate fish and possibly reptile remains. It is stated in MINISTERIO DE ENERGíA Y MiNAs (1997) that numerous fish remains are known from this formation, without any specifics on their exact location.

MOODY \& MAISEY (1994) reported on a fish assemblage from a locality west of Lake Maracaibo, Zulia State. The assemblage includes Squalicorax, Enchodus, Belonostomus, plethodids, and pachyrhizodontids. The material comes from a section of the La Luna Forma- 
tion just above its contact with the Maraca Formation, from strata that in Trujillo State also contain fish remains (RENZ 1982). According to MOODY \& MAISEY (1994: 3), their report of plethodids is the first from South America and "if Cenomanian in age, [they] are older than all North American examples". MoODY \& MAISEY (1994: 3) commented on the good quality of the three-dimensionally preserved pachyrhizodontids they studied.

The occurrence of plethodid fishes in the Cenomanian - Turonian was considered by TAVERNE \& GAYET (2005) together with other similar occurrences in other parts of Gondwana in a study of the biogeography of Tselfatiiformes fishes in the Cretaceous. They hypothesized a clock-wise spread of this group from the Euro-african Tethys to the South American Coast (localities in Venezuela and Colombia) and the Gulf of Mexico during this period, correlated with ocean drift currents in the Proto-Atlantic at the time.

WEILER (1940) had already described a fish fauna from the La Luna Formation, but from a locality in Táchira State, near San Cristobal. The whereabouts of the material are unknown (as also reported by MOODY \& MAISEY 1994), which included a new species of Cimolichthys and scales assigned to two other genera.

A "reptilian" tooth was reported by WEILER (1940: 246) from the La Luna Formation, from a site at the $12.5 \mathrm{~km}$ of the road connecting Tariba and Cordero (Táchira State). The tooth, the current location of which is unknown, was reportedly conical, robust, and with thin lines of enamel. WeILER (1940: 247) speculated that this tooth may have belonged to a mosasaur. The only certain and precisely-recorded mosasaur from La Luna Formation is presented for the first time in the last section of this paper.

\section{Querecual Formation, Cretaceous}

The Querecual Formation, present in the States Guárico, Anzoátegui and Sucre, is reported to be of Albian age, extending maximally to the Santonian (MINISTERIO DE ENERGÍA Y MINAS 1997). It is exposed in different localities and with different extensions along most of the Serranía del Interior in northeastern Venezuela, as well as in the Archipiélago Guaiquerí, in front of Puerto La Cruz. As summarized by MACSOTAY et al. (1985) and by MINISTERIO DE ENERGÍA Y MINAS (1997), numerous publications described foraminifera and other marine invertebrates from this formation, including radiolarians, bivalves and ammonites. Two areas in Sucre State are mentioned in MINISTERIO DE ENERGíA Y MINAS (1997) to contain "fossil fish": Cangrejal-río Coicual, and the area of Cangreja, cerro El Pato, El Algarrobo. The Querecual Formation may be to some extent equivalent to the La Luna Formation of western Venezuela, discussed above. The Formación Querecual is an important source of oil in eastern Venezuela (CAMPOS et al. 1985).
In the Querecual Formation indeterminate teleost fishes have also been found in Isla Chimana Grande, in front of Puerto La Cruz in Anzoátegui State. According to MACSOTAY et al. (1985), most of the skeleton of a fish, excluding the skull, is located on sediments exposed in an area next to the northeastern coast of the Island, in the embayment called "Las Plazuelos" (MACSOTAY et al. 1985: fig. 6A). The specimen is supposedly still in the outcrop.

COLBERT (1949) described a species of plesiosaur from two fossil localities in Guárico State reportedly from this formation, one containing the partial skeleton, whereas a second locality some $3 \mathrm{~km}$ distant from the first one contained a bone fragment. The main locality is about $6.5 \mathrm{~km}$ east and a little south of Altagracia de Orituco. COLBERT (1949) named the new species "Alzadasaurus tropicus". The type (AMNH 6796) is a dorsal vertebra and the described material includes the last twelve cervical vertebrae and associated ribs, the left scapula, coracoid, humerus, portions of radius, ulna, carpus, and fragments. Vertebral proportions and shape and height of the neural spines were important features in the description and diagnosis of this species. COLBERT (1949: 8-9) noted that the length of the centrum of the preserved vertebra is about equal to its height, as opposed to being significantly shorter than it is high, as in many other species of elasmosaurids. The taxonomic affiliation and significance of this material needs to be re-evaluated based on recent work on vertebral shape and proportions in plesiosaurs (e.g., O'KEFFE 2004; O'KEFFE \& HILLER 2006).

\section{Navay Formation, Cretaceous, Coniacian - Maastrichtian}

The Navay Formation has been subdivided into two members: the lower Quevedo Member and the upper La Morita Member (RENZ 1959; GAENSLEN 1962). GAENSLEN (1962) correlated the Quevedo Member with the middle and upper sections of the La Luna Formation. A series of studies of invertebrates and plants starting in the late $1950 \mathrm{~s}$ until the mid $1990 \mathrm{~s}$, summarized in MINISTERIO DE ENERGÍA Y MINAS (1997), have suggested diverging ages for the Navay Formation, which could be then estimated to be Coniacian - Maastrichtian in age.

PIERCE (1960) reported teleost fishes from the Barinas Basin, which he referred to the Clupeidae. SÁNCHEZ \& LORENTE (1977) described fish remains from Santa Bárbara de Barinas, from the Quevedo Member, which they referred to Gasteroclupea (Clupeidae), a genus previously reported from the upper Cretaceous of Bolivia and Argentina (SIGNEUX 1964; ARRATIA \& CIONE 1996). According to SÁNCHEZ \& LORENTE (1977), the Quevedo Member "se depositó a lo largo de una linea de costa, con numerosas desembocaduras de ríos que formaban estuarios, de aguas salobres, con PH menor de 7,8 y bien oxigenadas entre el límite de baja marea y la región litoral" (was deposited along the coast- 
line, with numerous river mouths forming estuarine conditions, with brackish waters, with a $\mathrm{pH}$ less than 7.8 and well oxygenated between the limit of low tide and the litoral region.).

PIERCE \& WELLS (1956) reported skeletal parts of mosasaurs, similar to those of Tylosaurus and Plesiotylosaurus from the Barinas Basin, three $\mathrm{km}$ northwest of Santa Bárbara of Barinas, from the Upper Cretaceous. Tylosaurus is one of the largest mosasaurs, and the earliest record of this genus is from the Lower Coniacian of western Kansas (EverharT 2005a). Plesiotylosaurus is a derived Mosasaurinae (RUSSELL 1967; BELL 1997), with a stratigraphic range expanding to the Maastrichtian.

\section{Burguita Formation, Cretaceous, Santonian - Maastrichtian}

Indeterminate fish remains were reported from the type section of the Burguita Formation in the Burgua-3 West Well (Pozo) of Apure State (MINISTERIO DE ENERGÍA Y MINAS 1997)

\section{Barranquín Formation, Lower Cretaceous}

Shark teeth were found by O. MACSOTAY from the Barranquín Formation (in OdREMAN \& MEDINA 1984; pers. comm. to MRSV in Jan. 2006). The fossils come from the Taguarumo Member (MACSOTAY et al. 1985) and were found in the Borracha and Chimana (= Puinare) islands, located a few kilometers away from the coast of Puerto La Cruz, Anzoátegui State.

As summarized by the MINISTERIO DE ENERGía Y MINAS (1997), diverging ages have been assigned to the Barranquín Formation, ranging from Neocomian up to Aptian - Albian. The type section is approximately 1,500 $\mathrm{m}$ thick (LIDDLE 1946). Studies of different parts of strata of the Barranquín Formation in several localities have resulted in diverging kinds of paleoenvironments being reconstructed for this formation (MINISTERIO DE ENERGía Y MINAS 1997).

\section{A new mosasaur locality from the La Luna Formation at Pozo Guapo, Lara State}

\section{Systematic paleontology}

\author{
Squamata OPPEL, 1811 \\ Mosasauroidea CAMP, 1923 \\ Mosasauridae GERVAIS, 1852 \\ Genus indet. \\ Figs. 1-4
}

Material: UNEFM-VF-39, skull fragments (Fig. 1), cervical vertebrae (Fig. 2A), dorsal vertebrae (Fig. 2B), phalanges (Fig. 3), probable stomach content (Fig. 4).

Locality and horizon: The site is located in the vicinity of the $\mathrm{Km} .55-56$ of the old road connecting Barquisimeto and
Carora, Distrito Torres, Lara State. The coordinates of the site are: $\mathrm{N} 10^{\circ} 10^{\prime} 06.8^{\prime \prime}, \mathrm{W} 69^{\circ} 45^{\prime} 32.8^{\prime \prime}$, taken by the senior author together with RL during a visit in 2007. The location and geological relations of this site within the La Luna Formation, called "Bloques de Pozo Guapo", are described by EvANOFF et al. (1960: 71). The fossil-bearing sediments are interpreted as being Turonian in age. Ammonites and bivalves are common in this site, and isolated fish scales are also present. Collector: Roberto Lozsán and collaborators (see Acknowledgements).

\section{Description \\ Skull fragments}

Two skull fragments of different size, comprising most of the anterior part of the muzzle, are preserved (Fig. 1). The small fragment consists of the tips of the lower jaw. The large fragment contains considerable portions of the medial parts of the hemimandibles and crushed remains of the upper jaw. Among the latter the right maxilla and the prefrontal of the same side can be clearly identified.

The maxilla is broken in two or three parts, which are separated from each other. The posterior part is the almost complete rear portion of this bone. It has a narrow triangular shape and ends acute posteriorly. The upper margin ascends oblique towards anterodorsal. The lower border runs straight and nearly parallel to the interior dorsal margin of the right hemimandible. At the ventral rim of the posterior part of the maxilla two recurved, slender conical teeth are found.

On the external surface of the anterior portion of the maxilla a few foramina, arranged in-line, can be seen. They are situated near the lower margin and run anteroposteriorly.

Anteroventral of the latter portion another toothbearing, small fragment is preserved, which also probably belongs to the same bone. At least two more slender, posteriorly recurved conical teeth can be recognized at the ventral margin of this fragment. These teeth are smaller than the two in the posterior part of the maxilla and decrease in size towards anterior. A less likely alternative interpretation of the small fragment is that it has been considerably displaced and belongs to the bony palate. In this case it would yield pterygoid teeth.

Viewed dorsally, the preserved parts of the lower jaw bear several medially recurved teeth inserted in alveoli. This condition is best seen in the right hemimandible, whereas the medial portion of the left hemimandible is mostly hidden by remains of the maxillae. The teeth in the lower jaw are firmly attached to the walls of the alveoli and are closely spaced. The apices of all teeth are missing and their subcircular cross-sections are visible. In the preserved parts of the right hemimandible are twelve alveoli. The alveoli and therefore the preserved teeth decline in size towards anterior. At least one tooth seems to be bicarinate. The anteriormost teeth are found near the front end of the lower jaw, which looks somewhat incomplete from dorsal. From ventral, 


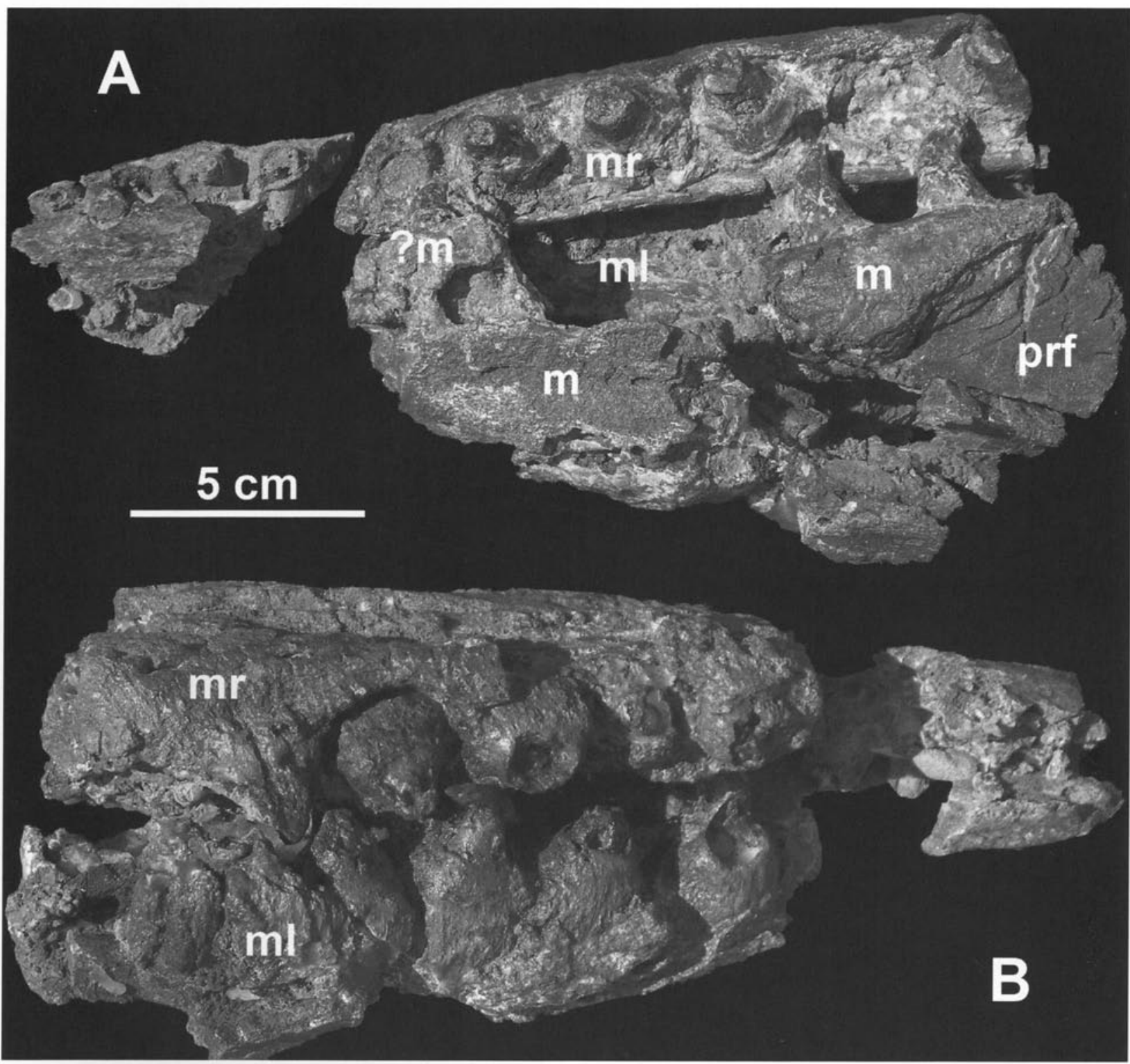

Fig. 1. Skull fragments of mosasaur UNEFM-VF-39. A: Dorsal and B: ventral view. The apices of the teeth of the lower jaws are missing (A). The ventral surfaces of the lower jaws are eroded and the roots of the teeth are exposed (B). - Abbreviations: $\mathrm{m}$, right maxilla; $\mathrm{ml}$, left mandible; $\mathrm{mr}$, right mandible; prf, right prefrontal.

however, it becomes evident that the missing anterior portions of the hemimandibles can only be very short. The ventral surface of the lower jaw is extensively eroded. As a result of this process, the roots of several teeth are exposed. The roots are bulbous and in contact with their respective neighbors.

\section{Cervical vertebrae}

Preserved are five procoelous cervical vertebral centra and some hypapophyses (Fig. 2A). The bones were hidden in a block of limestone, which broke up in such a manner that the imbedded fossils split roughly parallel to their median plane. Hence, the split centra and hypapophyses can be studied on the slab as well as on the counter-slab. Four of the five centra are more or less in articulation. The posteriormost centrum is slightly sep- arated from the other centra. Only the anterior third of this isolated centrum is preserved. The anteriormost centrum is also incomplete. In this case the anterior third of the bone is missing.

The complete cervical vertebral centra have a length of circa $3.5 \mathrm{~cm}$ each and are virtually square in anteroposterior section. The intervertebral articulations of the centra are vertical and gently bent. On the dorsal sides of the centra the bases of the neural arches can be seen.

Three hypapophyses are still in contact with the ventral margins of their respective centra. A short peduncle on the ventral surfaces for the articulation with the hypapophysis cannot be identified with certainty, but such a projection must be developed on those centra bearing a hypapophysis. The hypapophyses are antero- 


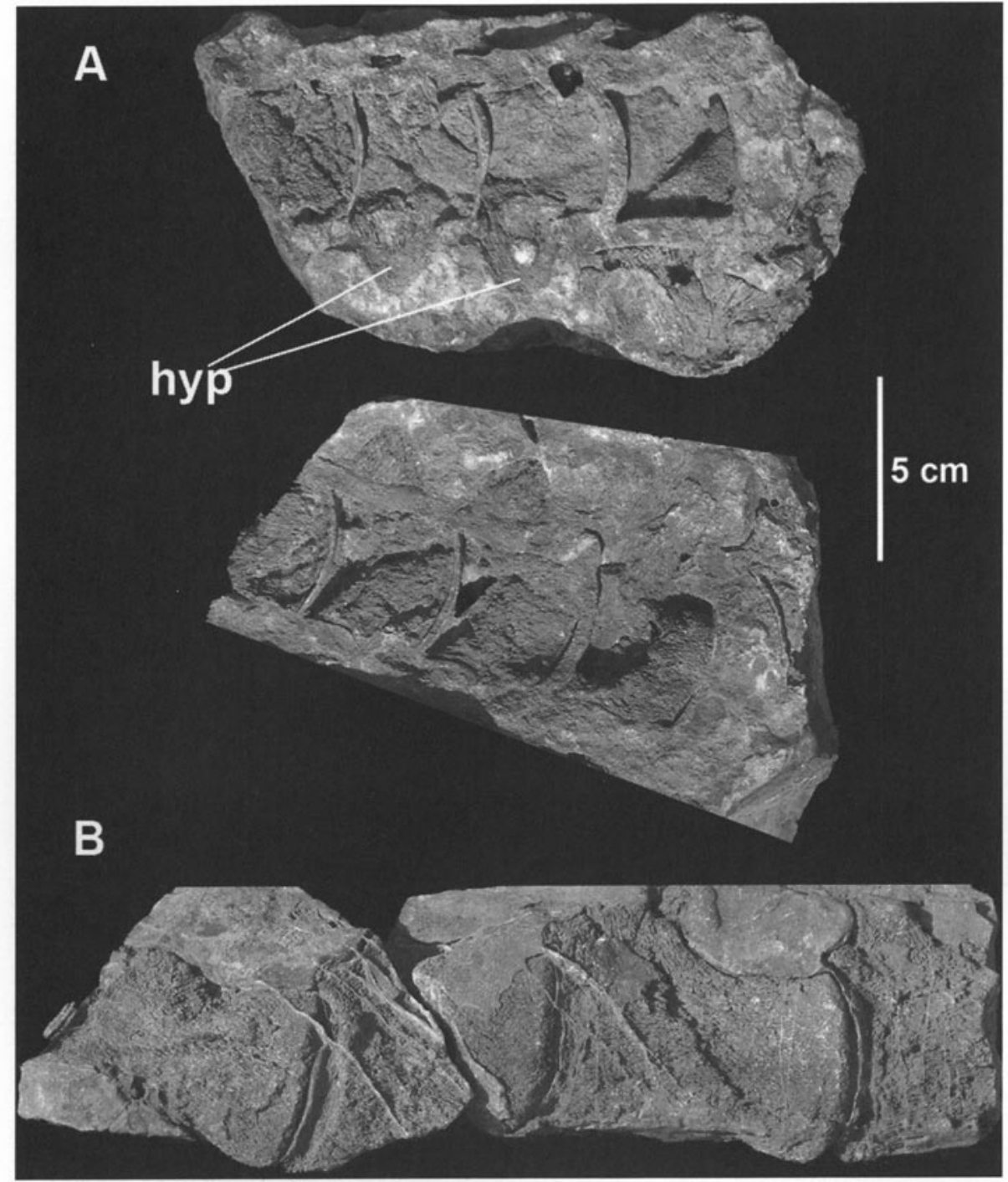

Fig. 2. Vertebrae of mosasaur UNEFM-VF-39. A: Cervical vertebrae (slab and counter-slab), split roughly parallel to their median plane. Preserved are procoelous vertebral centra and hypapophyses (hyp). - B: Dorsal vertebrae (two slabs belonging together). Preserved are procoelous vertebral centra. The third centrum displays the canal for the spinal cord. posteriorly broad, vertically orientated and taper ventrally.

\section{Dorsal vertebrae}

On two other slabs belonging to the same specimen, four procoelous dorsal vertebral centra can be identified (Fig. 2B). The first and the last centra are incomplete. Best preserved is the third centrum, which is visible in left laterodorsal view. These centra are considerably longer than the cervical vertebral centra. The third dorsal vertebral centrum visible has a length of approximately $8 \mathrm{~cm}$. The base of the neural arch and the canal for the spinal cord can be identified. The intervertebral articulations of the centra are gently bent and seem to be orientated vertical, as in the cervical series.

\section{Phalanges}

On another slab several flat, slender bones were found. They are arranged in successive couples and are interpreted as phalanges (Fig. 3). Most of them are strongly elongated and slightly constricted in their medial parts. All phalanges are incomplete, with the exception of the

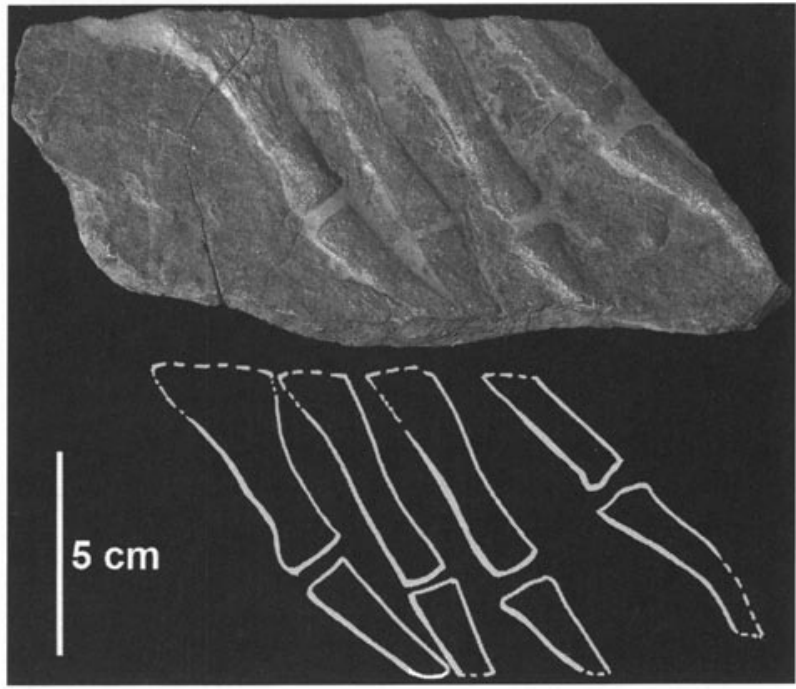

Fig. 3. Phalanges of mosasaur UNEFM-VF-39. The leftmost, distal element is interpreted as a terminal phalanx (compare with the drawing). 
Fig. 4. Probable stomach content of mosasaur UNEFM-VF-39. The large rodlike elements, best seen in the drawing, may be rib fragments. The smaller bowshaped elements are identified as ribs of a second, smaller individual tentatively referred to a plesiosaur.

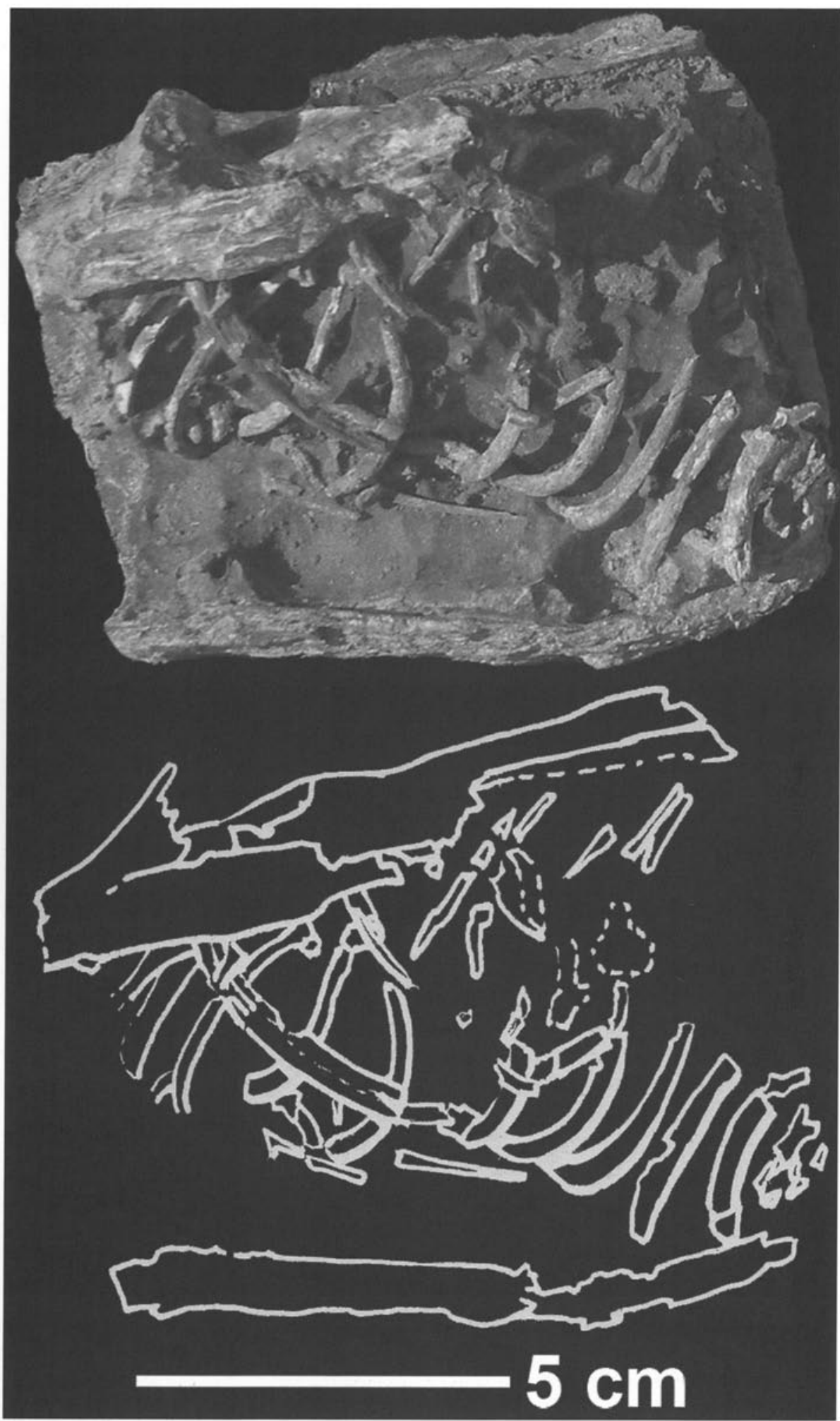

lower left element preserved on the slab. The width of this phalanx declines continuously distal, where the bone ends with a smooth rounding. By reason of the latter observation that element is identified as terminal phalanx.

\section{Probable stomach content}

On a very small slab (Fig. 4), measuring circa 8 to $10 \mathrm{~cm}$, several tiny bow-shaped elements can be seen, which are identified as ribs. They are proximal slightly broadened and seem to be single-headed. Some fragments of large bones of the mosasaur are associated with them.

\section{Discussion of the mosasaur material}

Remains of mosasauroids (Cenomanian to Maastrichtian) have been found on all continents, including Ant- 
arctica (EVERHART 2005b). They can be identified, amongst other apomorphies, by teeth with expanded, bulbous roots (BELL 1997; BELL \& POLCYN 2005), like those present in the material from the La Luna Formation. The morphology of the lower jaw and of the maxilla, as well as the maxilla/prefrontal-contact, combined with the shape of the phalanges reflects the conditions seen in mosasaurids (Fig. 1).

The oldest mosasaurids are known from the Turonian. The evolutionary history of this clade started with basal forms, including Clidastes, Tylosaurus, and Platecarpus (RUSSELL 1967). Soon mosasaurs inhabited the epicontinental seas of the world, where they lived as successful predators until the end of the Mesozoic (EVERHART 2005b). Within the Mosasauridae the clades Mosasaurinae, Russellosaurina (including Tylosaurinae and Plioplatecarpinae), and Halisauromorpha can be distinguished (BELL 1993; POLCYN \& BELL 2005).

Regarding the systematic position of the mosasaur remains from Venezuela within the mosasaurids the following attempt can be made: The flat, elongated phalanges (Fig. 4) with the slight constriction in their medial parts belong to a paddle-like autopodium, which is typical for hydropedal forms (BELL \& POLCYN 2005). The terms "plesiopedal" for amphibian Mosasauroidea retaining overall terrestrial limbs, and "hydropedal" for Mosasauridae evolving paddle-like structures or flippers were introduced by POLCYN \& BELL (2005). Elongated or spindle-shaped phalanges are widely spread within the derived Mosasauridae, with the exception of Mosasaurus and Plotosaurus, which are derived members of the Mosasaurinae (BELL 1997; BELL \& POLCYN 2005). The phalanges from Venezuela are similar to those of the plioplatecarpine Ectenosaurus (RUSSELL 1967: text-fig. 54).

The cervical vertebrae of UNEFM-VF-39 are distinctly shorter than the dorsal vertebrae (Fig. 2). This is also a common character of nearly all mosasaurs, again with the exception of Mosasaurus and Plotosaurus (BELL 1997; BELL \& POLCYN 2005).

If the intervertebral articulations of the dorsal vertebrae are really vertical, then Halisaurus and its closest relatives (Halosauromorpha) can also be excluded from a close relationship, because their dorsal vertebrae possess inclined condyles (BELL 1997; BELL \& POLCYN 2005).

Due to the imperfect preservation of the lower jaws of the specimen from Venezuela it cannot be determined with certainty, if a short projection of the dentary anterior to the first tooth was developed or not (Fig. 1). However, if such a projection was present, it was only short, and not as long as in the mosasaurine Plotosaurus or the tylosaurine Tylosaurus (BELL 1997; BELL \& POLCYN 2005).

There is space for twelve teeth in the collected portions of the incomplete right mandible of UNEFM-VF39. It is assumed that most of the right dentary is preserved, but the possibility that there was space in this bone for additional one or two teeth cannot be totally excluded. Thus, for the Venezuela mosasaurid, a range of twelve to fourteen dentary teeth is expected. Most of the mosasaurs with such a tooth count in the mandible belong to the Russelosaurina, to which all remains of derived pre-Coniacian mosasaurs with diagnostic features hitherto published can be referred (BELL \& POLCYN 2005). The parafamily Russellosaurina POLCYN \& BELL, 2005, comprises the Tylosaurinae, the Plioplatecarpinae, Tethysaurus, Russellosaurus, and Yaguarasaurus. Within the Russellosaurina, the similarity of the phalanges from Venezuela (Fig. 3) with those of Ectenosaurus and the missing ram-like prolongation of the lower jaws, characteristic for Tylosaurus, point to the Plioplatecarpinae, to which the mosasaurid material from Venezuela is tentatively referred. A derived member of the Plioplatecarpinae from the Turonian of Angola and perhaps additional material of the same clade and from the same age of North America are already known (LINGHAM-SOLIAR 1994; MARTIN \& STEWART 1977).

Regarding the small ribs, interpreted as probable stomach content, and the associated large fragments of the mosasaur, it should be noted that vertebrate remains swallowed by mosasaurs are known since 1919 (EVERHART 2003). More recently even evidence for live birth in mosasauroids has been reported. This observation is also established on the preservation of tiny remains found together with large mosasaur material (e.g., BELL et al. 1996). However, the small ribs discussed in this paper are too strongly bent and perhaps too broad proximally for foetal remains. Furthermore, they are plesiosaur-like and they are, therefore, tentatively referred to this group of marine reptiles. That mosasaurs fed on plesiosaurs has also been hypothesized since 1919 (EVERHART 2003). The large rod-like fragments associated with the small ribs may be remains of the rib cage of the mosasaur.

\section{Conclusion and prospects}

Continental microvertebrates are unknown from the Paleozoic and Mesozoic of Venezuela. The only relatively small vertebrates from this time and place are the La Quinta dinosaurs (BARRETT et al. 2008). Although shallow marine deposits are not the optimal kind of environment to look for them, screen-washing in them has resulted in surprising and important discoveries in other parts of the world, and could work also in Venezuela. For example, MARTIN et al. (2005) found a Late Cretaceous marsupial tooth of great biogeographic significance in fully marine deposits in the Netherlands.

The report of mosasaur remains from the La Luna Formation and the other discoveries summarized here are significant, given the paucity of marine reptiles from South America, where occurrences of marine reptiles are scarce and consist mostly of isolated remains of ich- 
thyosaurs and plesiosaurs (e.g., FERNÁNDEZ 1997), with a strong bias to Jurassic sites (e.g., GASPARINI et al. 2006). The only exception to this scarce South American record are the Jurassic reptiles found in the Neuquén Basin (GASPARINI \& FERNÁNDEZ 2005). Closer to the new Venezuelan register in time and location is the mosasaurid Yaguarasaurus columbianus from the Turonian (PÁRAMO-FONSECA 2000) of Colombia.

\section{Acknowledgments}

We thank P. Forey, P. Kenrick (NHM London), and O. Macsotay for discussions and/or for providing literature or advice, $\mathrm{C}$. Villalba and P. Lucena for assistance during fieldwork and $O$. Aguilera (Coro), L. Cavin (Geneva), and R. O'Keefe (Marshall University) for discussion of ideas and/or carefully reading of drafts of this manuscript. We thank B. Scheffold (Zürich) for the drawings. RL thanks S. Muñoz and I. Muñoz for help during the fieldwork leading to the discovery of Pozo Guapo mosasaur. For access to collections we thank M. Richter (NHM London). This study was supported by the Fonds zur Förderung des akademischen Nachwuchses (FAN) des Zürcher Universitätsvereins (ZUNIV).

\section{References}

ARRATIA, G. 2004. Mesozoic halecostomes and the early radiation of teleosts. - In: Arratia, G. \& Tintori, A., eds., Mesozoic Fishes 3 - Systematics, Paleoenvironments and Biodiversity: 279-316, München (F. Pfeil).

ARratia, G. \& CIONE, A. 1996. The record of fossil fishes in southern South America. - In: ARRATIA, G., ed., Contributions of southern South America to vertebrate paleontology. - Münchner Geowissenschaftliche Abhandlungen, Reihe A Geologie und Paläontologie 30: 9-72.

AVÉ Lallemant, H.G. \& Sisson, V.B., eds., 2005. Caribbean-South American plate interactions, Venezuela. - The Geological Society of America, Special Paper 394: 1-336.

BARRETT, P.M.; BUTLER, R.J.; NOVAS, F.E.; MOORE-FAY, S.; MOODY, J.M.; ClARK, J.M. \& SÁNCHEZ-VILlaGRA, M.R. 2008. Dinosaur remains from the La Quinta Formation (Lower or Middle Jurassic) of the Venezuelan Andes. - Paläontologische Zeitschrift 82 (2): 163-177.

BELL, G.L. Jr. 1993. A phylogenetic analysis of mosasauroidea (Squamata). - Ph.D. dissertation, University of Texas. -293 p., Austin (unpublished).

BELL, G.L. Jr. 1997. A phylogenetic revision of North American and Adriatic Mosasauroidea. - In: CALlaway, J.M. \& NICHOLls, E.L., eds., Ancient marine reptiles: 293-332, San Diego (Academic Press)

BELL, G.L. Jr. \& POLCYN, M.J. 2005. Dallasaurus turneri, a new primitive mosasauroid from the Middle Turonian of Texas and comments on the phylogeny of Mosasauridae (Squamata). - Netherlands Journal of Geosciences. Geologie en Mijnbouw 84: 177192.

BELL, G.L. Jr.; SHELDON, M.A.; LAMB, J.P. \& MARTIN, J.E. 1996. The first direct evidence of live birth in Mosasauridae (Squamata): Exceptional preservation in Cretaceous Pierre Shale of South Dakota. - Journal of Vertebrate Paleontology 16 (Suppl. 3): $21 \mathrm{~A}$.

BENEDETTO, G. \& ODREMAN RIVAS, O. 1977. Nuevas evidencias paleontológicas en la Formación La Quinta, su edad y correlación con las unidades aflorantes en la Sierra de Perijá y Cordillera oriental de Colombia. - V. Congreso Geológico Venezolano, Memorias 1: 87-106.

BENTON, M.J. 2004. Vertebrate Palaeontology. $3^{\text {rd }}$ ed. -455 p., Oxford (Blackwell Publishing).

Boesi, T.; Galea, F.A.; Rojas, G.; Lorente, M.L.; DuráN, I. \& VELÁsQUEZ, M. 1988. Estudio estratigráfico del Flanco Norandino en el sector Lobatera-El Vigía. - III Simposio Bolivariano Exploración Petrolera de las Cuencas Subandinas. Sociedad Venezolana de Geólogos, Caracas, Memorias. 1: 1-41.

BOWEN, J.M. 1972. Estratigrafía del precretácico en la parte norte de la Sierra de Perijá. - Congreso Geológico Venezolano, Memorias 2: $729-761$.

BUTLER, R.J. 2005. The 'fabrosaurid' ornithischian dinosaurs of the Upper Elliot Formation (Lower Jurassic) of South Africa and Lesotho. - Zoological Journal of the Linnean Society 145: 175218.

CAMP, C.L. 1923. Classification of the lizard families. - Bulletin of the American Museum of Natural History 48: 289-481.

CAMPoS, V.; De CABRERA S. \& LANDER, R. 1985. Estratigrafía del noreste de Anzoátegui. - In: EsPEJo, A.; RIOS, J.H. \& BELLIZZIA, N.P., eds., VI. Congreso Geológico Venezolano, Caracas, Memorias 1: 156-200.

CAVIN, L. 2001. Osteology and phylogenetic relationships of the teleost Goulmimichthys arambourgi CAVIN, 1995 from the Upper Cretaceous of Goulmima, Morocco. - Eclogae Geologicae Helvetiae 133: $25-52$.

COLBERT, E.H. 1949. A new Cretaceous plesiosaur from Venezuela. American Museum Novitates 1420: 1-22.

EvanofF, J.; Bushman, J.R. \& ARAujo, E. 1960. Bloques de rocas antiguas incrustados en sedimentos del Terciario Inferior en la Cuenca de Lara. - Boletín de Geología (Venezuela) 5 (10): 6779.

EVERHART, M.J. 2003. Plesiosaurs as the food of mosasaurs; new data on the stomach contents of a Tylosaurus proriger (Squamata; Mosasauridae) from the Niobrara Formation of western Kansas. - The Mosasaur 7: 41-46.

EVERHART, M.J. 2005a. Earliest record of the genus Tylosaurus (Squamata; Mosasauridae) from the Fort Hays Limestone (Lower Coniacian) of western Kansas. - Transactions of the Kansas Academy of Science 108: 149-155.

EVERHART, M.J. 2005b. Rapid evolution, diversification and distribution of mosasaurs (Reptilia; Squamata) prior to the K-T Boundary. - Tate 2005, Annual Symposium in Paleontology and Geology, Casper, WY, 11: 16-27.

FERNÁNDEZ, M. 1997. On the paleogeographic distribution of Callovian and Late Jurassic ichthyosaurs. - Journal of Vertebrate Paleontology 17 (4): 752-754.

FORERO, A. 1990. The basement of the eastern Cordillera, Columbia: an allochthonous terrane in northwestern South America. Journal of South American Earth Sciences 3: 141-151.

GAENSLEN, G. 1962. A discussion of the Cretaceous stratigraphy of the southwest Barinas mountain front (Nota técnica). - Asociación Venezolana de Geología, Minas y Petróleo, Boletín Informativo 5: $65-74$.

GASPARINI, Z. \& FERNÁNDEZ, M. 2005. Jurassic marine reptiles of the Neuquén Basin: records, faunas and their palaeobiogeographic significance. - In: VEIGA, G.D.; SPAllETTI, L.A.; HowELL, J.A. \& Schwarz, E., eds., The Neuquén Basin, Argentina: A case study in sequence stratigraphy and basin dynamics. - Geological Society London, Special Publication 252: 272-294.

GASPARINI, Z.; POL, D. \& SPALleTtI, L.A. 2006. An unusual marine crocodyliform from the Jurassic-Cretaceous boundary of Patagonia. - Science 311: 71-73.

Gervais, P. 1852. Zoologie und Paléontologie Françaises. Animaux Vertebré. - 271 p., Paris (Arthus Bertrand).

González de Juana, C.; ITURRalde de Arozena, J. \& PiCARd, X. 1980. Geología de Venezuela y de sus cuencas petrolíferas. 1031 p., Caracas (Ediciones Foninves). 
HuRley, I.A.; LOCKRIDGE MUELleR, R.; DUNN, K.A.; SCHMIDT, E.J.; FRIEDMAN, M.; Ho, R.K.; PrINCE, V.E; YANG, Z.; THOMAS, M.G. \& COATES, M.I. 2007. A new time-scale for ray-finned fish evolution. - Proceedings of the Royal Society (B) 274: 489498.

KUNDING, E. 1938. Las rocas precretáceas de los Andes centrales de Venezuela con algunas observaciones sobre su tectónica. - Boletín de Geología y Minas, Caracas 2 (2 \& 4): 21-43.

LiDDLE, R.A. 1946. The geology of Venezuela and Trinidad, $2^{\text {nd }}$ ed. 890 p., Ithaca, NY (Paleontological Research Institute).

LINGHAM-SOLIAR, T. 1994. The mosasaur "Angolasaurus" bocagei (Reptilia: Mosasauridae) from the Turonian of Angola re-interpreted as the earliest member of the genus Platecarpus. - Paläontologische Zeitschrift 68: 267-282.

MACSOTAY, O. 1980. Mollusques benthiques du Crétace inférieur; une méthode du corrélation entre la Tethys mésogéenne et le domaine paléo-Caraibe (Venezuela). - These d'Université, Univ. Claude Bernard, Lyon. - 168 p., Lyon (unpublished).

Macsotay, O; Vivas, V.; Pimentel, N. \& Bellizia, A. 1985. Estratigrafía y tectónica del Cretáceo-Paleoceno de las islas al norte de Puerto La Cruz-Santa Fé y regiones adyacentes. Excursión. - VI. Congreso de Geología de Venezuela, Caracas 10: 7125-7175

MAISEY, J.G. \& MOODY, J.M. 2001. A review of the problematic extinct teleost fish Araripichthys, with a description of a new species from the Lower Cretaceous of Venezuela. - American Museum Novitates 3324: 1-27.

MARTiN, J.E.; CASE, J.A.; JAGT, J.W.M.; SChulP, A.S. \& MuldER, E. W.A. 2005. A new European marsupial indicates a Late Cretaceous high-latitude transatlantic dispersal route. - Journal of Mammalian Evolution 12: 495-511.

MARTIN, L.D. \& STEWART, J.D. 1977. The oldest (Turonian) mosasaurs from Kansas. - Journal of Paleontology 51: 973-975.

Ministerio DE ENERGía Y MiNAS. 1997. Léxico Estratigráfico de Venezuela, $3^{\text {rd }}$ ed. - Boletín de Geología 12: 1-828.

MojiCA, J. \& Villaroel, C. 1990. Sobre la distribución y facies del Paleozoico Inferior sedimentario en el extremo NW de Suramerica. - Geología Colombiana 17: 219-226.

MoODY, J.M. 1997. Theropod teeth from the Jurassic of Venezuela. Boletín de la Sociedad Venezolana de Geología 22: 37-42.

MoOdY, J.M. \& MAISEY, J.G. 1994. New Cretaceous marine vertebrate assemblages from north-western Venezuela and their significance. - Journal of Vertebrate Paleontology 14 (1): 18.

ODREMAN RIVAS, O.E. 1997. Lista actualizada de los fósiles de Venezuela. - In: LA MARCA, E., ed., Vertebrados actuales y fósiles de Venezuela. - Serie Catálogo Zoológico de Venezuela, 1. Mérida (Museo de Ciencia y Tecnología de Mérida).

OdReman Rivas, O.E. \& Benedetto, G. 1977. Paleontología y Edad de la Formación Tinacoa, Sierra de Perijá, Estado Zulia, Venezuela. - Memorias del V Congreso Geológico Venezolano 1: 1532.

OdREMAN RIVAS, O.E. \& MEDINA, C.J. 1984. Vertebrados fósiles de Venezuela, secuencia, relaciones con otros paises de América del Sur. - Cuadernos de Geología, Ministerio de Energía y Minas 1: $60-86$.

O'KEEFE, F.R. 2004. Preliminary description and phylogenetic position of a new plesiosaur (Reptilia: Sauropterygia) from the Toarcian of Holzmaden, Germany. - Journal of Paleontology 78 : 973-988.

O'KEEFE, F.R. \& HILLER, N. 2006. Morphologic and ontogenetic patterns in elasmosaur neck length, with comments on the taxonomic utility of neck lengths variables. - Paludicola 5: 206229.

OPPEL, M. 1811. Die Ordnungen, Familien und Gattungen der Reptilien als Prodom einer Naturgeschichte derselben. -87 p., $\mathrm{Mu}-$ nich (Joseph Lindauer).

PÁRAMO-FONSECA, M.E. 2000. Yaguarasaurus columbianus (Reptilia, Mosasauridae), a primitive mosasaur from the Turonian
(Upper Cretaceous) of Colombia. - Historical Biology 14: 121131.

PIERCE, G.R. 1960. Geología de la Cuenca de Barinas. - III. Congreso Geológico Venezolano, Caracas, 1959, Memorias 1: 214-276.

PIERCE, G.R.; JeFFERson, C.C. \& SMITH, W.R. 1961. Fossiliferous Paleozoic localities in Mérida Andes, Venezuela. - Bulletin of the American Association of Petroleum Geologists 45: 342375.

PierCe, G.R. \& Wells, S.P. 1956. Primer hallazgo de restos de mosasauro en el Cretáceo de Santa Bárbara de Barinas, Venezuela. Sociedad Venezolana de Ciencias Naturales, Boletin 17: 21-24.

POLCYN, M.J. \& BELL, G.L. Jr. 2005. Russellosaurus coheni n. gen., n. sp., a 92 million-year-old mosasaur from Texas (USA), and the definition of the parafamily Russellosaurina. - Netherlands Journal of Geosciences. Geologie en Mijnbouw 84 (3): 321-333.

RENZ, O. 1959. Estratigrafía del Cretáceo en Venezuela occidental. Boletín de Geología, Caracas 5: 3-48.

RENZ, O. 1982. Cretaceous ammonites of Venezuela. - 132 p., Caracas (Maraven).

RusSELL, D.A. 1967. Systematics and morphology of American mosasaurs (Reptilia, Sauria). - Bulletin of the Peabody Museum of Natural History, Yale University 23: 1-241.

Russell, D.E.; Rivas, O.O.; BATTAIl, B. \& Russell, D.A. 1992. Découverte de vertébrés fossils dans la Formation de La Quinta, Jurassique du Vénézuela Occidental. - Comptes Rendus de l'Académie des Sciences, Paris, Série II 314: 1247-1252.

SÁNCHEZ, T.M. \& BENEdETTo, G. 1979. Una dentición de tipo pycnodontiforme del Paleozoico Superior de los Andes de Venezuela. - Geos 25: 13-18.

SÁnChez, T.M. \& LoRENTE, M.A. 1977. Paleoambiente del Miembro Quevedo (Formación Navay) en las proximidades de Santa Bárbara. - V. Congreso Geológico Venezolano, Memorias 1: 107133.

SÁNCHEZ-VILLAGRA, M.R. \& ClARK, J.M. 1994. An ornithischian from the Jurassic of the Venezuelan Andes. - Journal of Vertebrate Paleontology 14 (Suppl. 3): 44A.

SCHUBERT, C. 1986. Stratigraphy of the Jurassic La Quinta Formation, Mérida Andes, Venezuela: type section. - Zeitschrift der Deutschen Geologischen Gesellschaft 137 (1): 391-411.

TAVerne, L. \& Gayet, M. 2005. Phylogenetical relationships and palaeozoogeography of the marine Cretaceous Tselfatiiformes (Teleostei, Clupeocephala). - Cybium 29: 65-87.

Tribovillard, N.-P.; Stephan, J.-F.; MANIVIT, H.; ReYre, Y.; Cotillon, P. \& Jautée, E. 1991. Cretaceous black shales of Venezuelan Andes: preliminary results on stratigraphy and paleoenvironmental interpretations. - Palaeogeography, Palaeoclimatology, Palaeoecology 81: 313-321.

WEILER, W. 1940. Fischreste aus der Umgebung von San Cristobal, SW. Venezuela. - Zentralblatt für Mineralogie, Geologie und Paläontologie (B) 1949: 240-255.

YOUNG, G.C. 1990. Devonian vertebrate distribution patterns and cladistic analysis of palaeogeographic hypotheses. - In: MCKERROW, W.S. \& SCOTESE, C.R., eds., Palaeozoic Palaeogeography and Biogeography. - Geological Society Memoir 12: 243-255.

YoUNG, G.C. 2005. An articulated phyllolepid fish (Placodermi) from the Devonian of central Australia: implications for non-marine connections with the Old Red Sandstone continent. - Geological Magazine 142: 173-186.

Young, G.C. \& MoODY, J.M. 2002. A Middle-Late Devonian fish fauna from the Sierra de Perijá, western Venezuela, South America. - Mitteilungen des Museums für Naturkunde Berlin, Geowissenschaftliche Reihe 5: 155-206.

Young, G.C.; Moody, J.M. \& CASAS, J. 2000. New discoveries of Devonian Vertebrates from South America, and implications for Gondwana-Euroamerica contact. - Comptes Rendus de l'Académie des Sciences, Paris 331: 755-761.

Manuskripteingang / manuscript received 14. 6. 2007; Manuskriptannahme / manuscript accepted 18. 3. 2008. 